Proceedings of the 2nd international conference Economic and Business Trends Shaping the Future | 2021

\title{
DEVELOPING AND MEASURING SOFT SKILLS AFTER ONLINE TRAININGS
}

\author{
Ivona Litsova \\ Faculty of Economics and Business Administration - Sofia University "St. Kliment Ohridski" \\ ihristova777@abv.bg
}

\begin{abstract}
Working remotely has become a common approach for many companies in the past year. This raises several questions including the work-life balance and worker's effectiveness in the homeoffice environment. Here also comes the question of the training of employees and how to develop them in the new working set-up. Online programs become more and more popular among the employers. They can be in the form of webinars, virtual classrooms, conferences, etc. A focus of this article is to outline the ways to measure soft skills after online trainings. I did a literature review which covers books and journals on soft skills measurement topic with the purpose to clarify the methodology for evaluation of the results after online courses. The article provides additional findings from the conducted survey among the regular employees in a technical company from the IT sector in Eastern Europe. The outcomes from it confirmed that reactions are what organizations usually measure and it is done by using feedback forms during or after the course which helps to improve the future sessions. Learning objectives should be defined in advance and can be measured during the training by carefully observing the participation of the trainees. Results could be measured on a later stage after careful consideration of the productivity of the employee and analysis of his/ her feedback, behavior and changes in the working process after the course. Kirkpatrick's model will be the starting point of the discussion in the context of the following steps for evaluation - reaction, learning, behavior and results.
\end{abstract}

Keywords: soft skills, training and development, online courses, training evaluation

JEL classification: 015 , E24

\section{INTRODUCTION}

Soft skills trainings attract the interest of the companies as a way to increase productivity and the effectiveness of the employees. These courses help to reduce the time it takes for a learner to become productive and thus reduces the Time to Competence which is a goal for many organizations (Bachvarova et al, 2012). Face-to-face training is considered as the traditional approach but it may be difficult or costly to access for people who live a long distance from the education venue (Malony et al, 2011). Web-based delivery of educational content provides flexibility of access and promotes a learner-centered approach to learning, enabling interaction with learning materials at a time that suits the consumer (Biggis, 1999).

In this paper I aim to give an overview of several existing models for evaluating soft skills trainings and present a survey on the measurement of these skills using Kirkpatrick's model as a reference. The article is organized as follows: in Section 2 I present the literature review and the structure and findings of the conducted survey. In Section 3 I show and discuss the outcomes from the survey. The last section includes the conclusion and the future research ideas.

http://hdl.handle.net/

http://doi.org/10.47063/EBTSF.2021.0018 


\section{METHODOLOGY AND DATA}

\subsection{Literature review}

This article includes the following criteria when choosing the proper literature:

- Papers published from 1994 - 2019

- Papers with the keywords "soft skills measurement" OR "soft skills training evaluation" OR "soft skills" OR "training evaluation methods" OR "Kirkpatrick's model"

I chose only articles that can be relevant to soft skills measurement in the work environment since there are models and technics that are presented only for students at schools or universities and cannot be applicable. The review includes definitions of soft skills, most common non-technical skills, measurement technics and models.

A simple definition of Soft Skills comes from the winner of the Nobel prize 2000 for Economics James Heckman: "Soft Skills predict success in life" (Cimatti, 2016). A distinction can be made between Selforiented skills - what the person must understand and develop by himself and Interpersonal Skills - what the person can develop relating with other people. This distinction can also be made in terms of Personal and Social Skills. Personal Skills mainly correspond to cognitive Skills, such as knowledge and thinking skills while Social Skills refer to relationships with other people (Engelberg, 2015). Gallivan et al., (2004) identified the six most common non-technical skills mentioned in employment advertisements as 1) communication, 2) interpersonal, 3) leadership, 4) organization, 5) self-motivation, and 6) creativity.

Soft skills are most often measured using survey questions that ask respondents to self-assess their personality characteristics (Deming, 2014). The Big 5 personality inventory is a psychological model that divides human personality into five factors - extraversion, conscientiousness, agreeableness, neuroticism, and openness to experience (Srivastava \& John, 1999). Big 5 personality measures are positively correlated with educational attainment, labor market earnings, and other important life outcomes (Heckman \& Kautz, 2012).

Reading the Mind in the Eyes Test (RMET) is a measure of emotion recognition or social sensitivity (Kohen et al, 2001). It was originally created to diagnose "theory of mind" deficits such as Asperger syndrome and high-functioning autism, but psychologists have discovered that the RMET has predictive power for a wide variety of outcomes within a general population (Deming, 2014).

The Kirkpatrick's model created by Donald Kirkpatrick is applicable for soft skills trainings as well. It presents evaluation methods and connects this to four different levels: reaction, learning, behavior and results (Kirkpatrick, D.J., 1994). Reaction shows how the participants felt about the training/ learning experience; learning presents the measurement of the increase of knowledge before and after the training; behavior shows the extent of the applied learning on the job; what is implemented from the training in the working environment and results describe the effects on the business/ environment by the trainee.

\subsection{Data collection}

For the purposes of the article, I arranged a survey among working people between 25 and 35 years in a technical company in Bulgaria. People are specialists and no one of them is a supervisor. The questionnaire is available in Appendix 1. With this survey I wanted to apply the Kirkpatrick's model for measuring soft skills after trainings in this company, having in mind that currently all 
trainings are web-based. The survey includes 7 questions on the topic and 3 demographic questions.

\section{RESULTS AND ANALYSIS}

I presented the survey in a middle-sized company and 45 people took part in it so far. 30 of them are between 25-27 years old, 8 are between $28-30$ and 4 are in the range 31-33 and 3 are 34-35 years old. 15 of the participants are part of the HR team, 5 are from the IT department, 7 are from the Marketing team, 9 are from the Sales team and 9 are from the Technical support. The survey was conducted by 21 women and 24 men. In the table below I present a summary of the results from the main questions.

Table 1: Survey results

\begin{tabular}{|c|c|}
\hline & \\
\hline Question & Answer \\
\hline $\begin{array}{l}\text { What are the main soft skills that are evaluated } \\
\text { after online trainings in your company? }\end{array}$ & $\begin{array}{l}\text { Ranking is based on the number of people who } \\
\text { chose it (1-the most popular choice, } 5 \text { - the least } \\
\text { popular choice): 1. Communication, } 2 . \\
\text { Negotiation skills, 3. Leadership, 4. Self- } \\
\text { motivation, 5. Creativity }\end{array}$ \\
\hline $\begin{array}{l}\text { Do you sign in an attendance sheet/ confirm } \\
\text { your presence virtually when the training } \\
\text { starts online? }\end{array}$ & $\begin{array}{l}\text { In the online trainings all of the participants say } \\
\text { that they confirm their presence: } 17 \text { people - } \\
\text { "By turning on the camera" and } 28 \text { people said } \\
\text { that "This happens automatically - when I join, } \\
\text { it appears on the screen of the trainer". }\end{array}$ \\
\hline $\begin{array}{l}\text { Do you fill-in a feedback form when the } \\
\text { training is over? }\end{array}$ & $\begin{array}{l}37 \text { people fill-in training form and } 8 \text { people do } \\
\text { not do it }\end{array}$ \\
\hline $\begin{array}{l}\text { How relevant was the content of the last } \\
\text { online course you attended for your current } \\
\text { work role? }\end{array}$ & $\begin{array}{l}\text { It was "very relevant" for } 28 \text { people, "not that } \\
\text { relevant" for } 9 \text {, "more relevant than not" for } 5 \\
\text { and "not relevant at all" for } 3 \text { people. }\end{array}$ \\
\hline $\begin{array}{l}\text { How much time do you spend with the } \\
\text { learning resources from a training? }\end{array}$ & $\begin{array}{l}13 \text { people spend between } 2-3 \text { hours, } 17 \text { people } \\
\text { spend between } 1-2 \text { hours and } 15 \text { people spend } \\
\text { no more than } 1 \text { hour. }\end{array}$ \\
\hline $\begin{array}{l}\text { Have you ever been asked to fill-in a } \\
\text { knowledge test after the training is over? }\end{array}$ & 11 people - yes, and 34 people - no \\
\hline $\begin{array}{l}\text { Do you notice a change in your work } \\
\text { relationships after the training? }\end{array}$ & $\begin{array}{l}29 \text { of the participants usually notice a change } \\
\text { after the training and } 16 \text { people do not notice } \\
\text { any change. }\end{array}$ \\
\hline
\end{tabular}

Kirkpatrick's model proposes that training effects be examined for four levels of impact: (1) participant reaction, (2) participant knowledge, (3) participant change in behavior, and (4) change in outcomes (Hutchinson, 1999). Level 1 outcomes were measured through program attendance, self-reported satisfaction, participants' ratings of the relevance of the program content to their current work roles, and self-reported estimates of time spent engaged with the learning resources. Level 2, knowledge, could be measured via a knowledge test, conducted after completion of the training. Level 3 outcomes could be measured by a self-report of whether participants had changed their practices since completing the program and this change is measured through the question "Do you notice a change in your work relationships after the training?" and then, by open text comment, "If you answered positive to the question above, please indicate in what way the program changed 
your behavior" (Maloney et al, 2011). The results so far confirmed the application of Kirkpatrick's model for evaluation of soft skills trainings when the course is web-based.

\section{CONCLUSION}

This paper is a preliminary work on the metrics that could be used to measure the soft skills after trainings. The companies invest in courses that will develop specific personal skills of the employees and will return the investment in the future. Kirkpatrick's model is a key point of the analysis and the conducted survey aims to prove how it could be applied for web-based soft skills trainings.

Future work on this topic will include a deeper analysis of the arranged online courses and will focus on Level 4 (Results) of the Kirkpatrick's model. The survey could be extended to companies in different fields and interviews with managers would help understand how the results from nontechnical trainings can be measured.

\section{REFERENCES}

Bachvarova, Y., Bocconia, S., van der Polsa, B., Popescu, M. and Roceanu, I. (2012), "Measuring the effectiveness of learning with serious games in corporate training", Procedia Computer Science, Vol. 15, pp. 221 - 232, available at: https://core.ac.uk/download/pdf/82134732.pdf (accessed on August 30th 2021)

Baron-Cohen, S., Wheelwright, S., Hill, J., Raste, Y. and Plumb, I. (2001), "The 'Reading the Mind in the Eyes' Test Revised Version: A Study with Normal Adults, and Adults with Asperger Syndrome or High-Functioning Autism," Journal of Child Psychology and Psychiatry, 42(2), pp. 241-51.

Biggs, J. (1999), "What the student does: teaching for enhanced learning", Higher Educ Res Dev, Vol. 18(1), pp.57-75, available at: https://www.researchgate.net/publication/228559299 (accessed on October 20th 2021).

Cimatti, B. (2016), “Assessment of Soft Skills and their Role for the Quality of Organizations and Enterprises", International Journal for Quality Research, Vol.10(1), pp. 97-130 ISSN 1800-6450. Engelberg, S. (2015), A developmental Perspective on Soft Skills. Speech at "Soft Skills and their role in employability - New perspectives in teaching, assessment and certification", workshop in Bertinoro, FC, Italy.

Gallivan, M., Truex III, D. and Kvasny L. (2004), "Changing Patterns in IT Skill Sets 1998-2003: A Content Analysis of Classified Advertising," Database for Advances in Information Systems, Vol. 35, No. 3, pp. 64-86.

Heckman, J. and Kautz, T. (2012), "Hard Evidence on Soft Skills", NBER Working Paper 18121, June 2012, and Labour Economics, 19(4), pp. 451-64.

Hutchinson, L. (1999), "Evaluating and Researching the Effectiveness of Educational Interventions", BMJ, May 8;318(7193), pp.1267-1269

John, O. and Srivastava, S. (1999), "The Big Five Trait Taxonomy: History, Measurement, and Theoretical Perspectives," in L. Pervin, O. John, eds., Handbook of Personality: Theory and Research, New York: The Guilford Press, pp. 102-38

Kirkpatrick, D.L. (1994), “Evaluating Training Programs: The Four Levels”, Berret-Koehler, San Francisco, p. 229.

Maloney, S., Haas, R., Keating, J.L., Molloy, E., Jolly, B., Sims, J., Morgan, P., Haines, T. (2011), "Effectiveness of Web-Based Versus Face-To-Face Delivery of Education in Prescription of FallsPrevention Exercise to Health Professionals: Randomized Trial”, J Med Internet Res, 13(4):e116, 
available at: http://www.jmir.org/2011/4/e116/ doi: 10.2196/jmir.1680 PMID: 22189410 (accessed on October 15 th 2021).

\section{Appendix 1}

Survey questions
Age
Gender
Department
a. $25-27$
a. Male
a. Human resources
b. $28-30$
b. Female
c. $31-33$
c. I do not want to specify
b. Marketing
c. Sales
d. $34-35$
d. Technical support
e. IT

1. What are the main soft skills that are evaluated after online trainings in your company?

a. Self-motivation

b. Negotiation skills

c. Communication skills

d. Leadership

e. Creativity

2. Do you sign in an attendance sheet/ confirm your presence virtually when the training starts online?
a. Yes - by turning on the camera
b. Yes - this happens automatically when I join the session
c. No
d. I do not remember

3. Do you fill-in a feedback form when the training is over?

a. Yes

b. No

c. I do not remember

4. How relevant was the content of the last online course you attended for your current work role?
a. very relevant
b. more relevant than not
c. not that relevant
d. not relevant at all

5. How much time do you spend with the learning resources from a training?

a. 2-3 hours

b. 1-2 hours

c. no more than 1 hour

6. Have you ever been asked to fill-in a knowledge test after the training is over?

a. Yes

b. No

7. Do you notice a change in your work relationships after the training? If you answer positive to the question above, please indicate in what way the program changed your behavior. 
a. Yes, I notice a change (specify what change, e.g. "I attempt to use more motivational interviewing techniques", "I become more assertive when communicating", "I try to balance my emotions at work")

b. No, I do not notice any change 